\title{
LEGISLATION FOR DISABLED PEOPLE IN BRAZIL. FROM HUMAN DIGNITY TO SOCIAL INCLUSION.ADVANCING CAPABILITIES AS AN ETHICAL IMPERATIVE
}

\begin{abstract}
Rosylane Nascimento das Mercês Rocha ${ }^{1}$, Josierton Cruz Bezerra ${ }^{2}$, Francisco Cortes Fernandes ${ }^{3}$, Mónica Correia ${ }^{4}$, Rui Nunes ${ }^{5}$.

Abstract The study analyzes the ethical and legal basis of Brazilian legislation for people with disabilities and verifies whether the instruments used therein are in line with national and international law. It also investigates the coherence and cohesion of the law and its ethical norms to build an inclusive and just society. Through an exploratory and integrative review, it analyzed the legal provisions in force in Brazil published on the official websites of the Brazilian federal government and available on the Internet. It was evaluated whether the definition used for persons with disabilities follows the United Nations Convention on the Rights of Persons with Disabilities. Also, whether it is necessary to evaluate disabilities and who should perform this task professionally. Thirty-three legal norms were found, among which only three laws and two decrees are in line with the recommendations of the UN Convention. It is necessary to review the existing norms and promote the consolidation of laws, decrees, ordinances and normative instructions regarding the rights of persons with disabilities in a uniform manner, on an adequate technical-scientific basis. This review should be consistent with the provisions of the 1988 Federal Constitution, the International Convention on the Rights of Persons with Disabilities and the Brazilian Inclusion Law.
\end{abstract}

Keywords: disabled people; healthcare legislation; disability assessment.

Legislación para los discapacitados en Brasil. De la dignidad humana a la inclusión social. El avance de las capacidades como imperativo ético

Resumen: El estudio analiza el fundamento ético y jurídico de la legislación brasileña para las personas con discapacidad y comprueba si los instrumentos allí utilizados se ajustan al Derecho nacional e internacional. Además, investiga la coherencia y cohesión de la ley y sus normas éticas para construir una sociedad inclusiva y justa. Mediante revisión exploratoria e integrativa, analizó las disposiciones legales vigentes en Brasil publicadas en los sitios web oficiales del gobierno federal brasileño y disponibles en Internet. Se evaluó si la definición utilizada para las personas con discapacidad sigue la Convención de las Naciones Unidas sobre los Derechos de las Personas con Discapacidad. También, si es necesario evaluar las discapacidades y quién debe realizar esa tarea profesionalmente. Se encontraron 33 normas legales, entre las cuales solo tres leyes y dos decretos se ajustan a las recomendaciones de la Convención de las Naciones Unidas. Es necesario revisar las normas existentes y promover la consolidación de las leyes, decretos, ordenanzas e instrucciones normativas relativas a los derechos de las personas discapacitadas de manera uniforme, sobre una base técnico-científica adecuada. Esta revisión debe ser coherente con las disposiciones de la Constitución Federal de 1988, la Convención Internacional sobre los Derechos de las Personas con Discapacidad y la Ley de Inclusión brasileña.

Palabras clave: personas con discapacidad, legislación sanitaria, evaluación de la discapacidad

Legislaçáo para os incapacitados no Brasil. Da dignidade humana à inclusáo social. $\mathrm{O}$ avanço das capacidades como imperativo ético

Resumo: $\mathrm{O}$ estudo analisa o fundamento ético e jurídico da legislaçáo brasileira para as pessoas com incapacidade e comprova se os instrumentos ali utilizados se ajustam ao Direito nacional e internacional. Além disso, investiga a coerência e coesão da lei e suas normas éticas para construir uma sociedade inclusiva e justa. Mediante revisão exploratória e integrativa, analisou as disposições legais vigentes no Brasil publicadas nos sites web oficiais do governo federal brasileiro e disponíveis na Internet. Avaliou-se se a definição utilizada para as pessoas com incapacidade segue a Convençáo das Naçóes Unidas sobre os Direitos das Pessoas com Incapacidade. Também, se é necessário avaliar as incapacidades e quem deve realizar essa tarefa profissionalmente. Se encontraram 33 normas legais, entre as quais somente três leis e dois decretos se ajustam às recomendaçôes da Convençáo das Naçóes Unidas. É necessário revisar as normas existentes e promover a consolidação das leis, decretos, regulamentos e instruçôes normativas relativas aos direitos das pessoas incapacitadas de maneira uniforme, sobre uma base técnico-científica adequada. Esta revisão deve ser coerente com as disposiçóes da Constituição Federal de 1988, a Convenção Internacional sobre os Direitos das Pessoas com Incapacidade e a Lei de Inclusão brasileira.

Palavras chave: pessoas com incapacidade, legislação sanitária, avaliação da incapacidade

\footnotetext{
${ }^{1}$ Faculty of Medicine of the University of Porto, Portugal. State Department of Economics of the Federal District, Brasilia, Brazil. ORCID: 0000-0002-8773-1345. up201508531@med.up.pt

${ }^{2}$ National Social Security Institute, Natal, Rio Grande do Norte, Brazil. ORCID: 0000-0003-0046-967X. josierton@gmail.com

${ }^{3}$ Pontifical Catholic University of Goiânia, Goiás, Brazil. ORCID: 0000-0003-2298-8227. fcfster@gmail.com

${ }^{4}$ Faculty of Medicine of the University of Porto, Portugal. ORCID: 0000-0002-9034-7029. mcorreia@med.up.pt

${ }^{5}$ Faculty of Medicine of the University of Porto, Portugal. ORCID: 0000-0002-1377-9899. ruinunes@med.up.pt
} 


\section{Introduction}

Throughout history, disabled people have been regarded in different ways. From a religious point of view, their condition was considered the result of divine punishment at times. Also, they were regarded as responsible for their disability, and therefore individual adaptations would be needed to diminish their exclusion. It meant that usually, disability was equivalent to social and even familiar exclusion.

The social movements regarding disabled people in the developed world started in the 1970s. A social dimension was introduced, and diversity was added as a component of disability, but without ignoring the need to identify body injuries. A disabled person came to be defined as someone who presented long-term impairments of physi$\mathrm{cal}$, mental, intellectual, or sensory nature that, in interaction with a variety of barriers, might impede the individual's full and effective participation in society under conditions of equality of opportunity with other people(1). In specific cases, such as deaf people, this global movement led to the idea that deafness is not a disease or even a disability, but a "difference" so that the traditional models of observing disabled people should be deconstructed to be reconstructed in a different, unbiased, and just manner(2).

In Brazil, the constitution of 1988(3) imposed essential safeguards on the principle of equality for disabled people as a corollary of the value of human dignity. The text of the constitution established as a fundamental principle that the Federal government and the State and Federal District governments should legislate concurrently towards the protection and social integration of disabled people.

In 1989, general norms for ensuring full availability of individual and social rights for disabled people (the so-called "people with deficiencies") and their effective social integration were established through law no 7,853/1989(4). This law considered the fundamental values of equality of treatment and opportunity, social justice, respect for human dignity, well-being and other values indicated in the constitution or justified by the general principles of law. This law aimed to guar- antee disabled people's full use of fundamental rights. Those rights included education, healthcare, employment, leisure, social security, maternity and childhood protection, and other rights stemming from the constitution. Its laws would enable their personal, social, and economic wellbeing. The Department of Special Education of the Ministry of Education should be restructured to comply with this law's provisions. Besides, the Ministry of Work, the Ministry of Health and the Ministry of Social Security and Assistance should create sectorial coordination bodies concerning disabled people. However, the high-level coordination of issues and government actions and measures relating to disabled people would be the responsibility of the Special Department of $\mathrm{Hu}$ man Rights of the Presidency of the Republic.

To regulate law $n^{\circ} 7,853 / 1989$, decree $n^{\circ}$ 3,298/1999 was published(5). This legal instrument instituted the national policy for integrating disabled people, which had the following principles:

Development of joint action between the State and civil society to ensure full integration of disabled people within the socioeconomic and cultural context

Establishment of legal and operational mechanisms and instruments for ensuring that disabled people would be able to fully use their fundamental rights that, stemming from the constitution and its laws, would enable their personal, social and economic well-being

Respect for disabled people, who should receive equality of opportunities within society through recognition of their guaranteed rights, without privileges or paternalism

The objectives of this policy were:

Enablement of access to, entry to and presence at all services offered to the community for disabled people;

Integration of the actions of public and private bodies and entities in the fields of healthcare, education, work, transportation, social assistance, construction, social security, housing, culture, 
sports and leisure, with the aim of prevention of deficiencies, elimination of their multiple causes and enablement of social inclusion;

Development of sectorial programs destined for meeting the unique needs of disabled people;

Training of human resources for attending to disabled people; and

To ensure the effectiveness of preventive programs, specialised attendance and social inclusion.

Since the United Nations Convention on the Rights of Persons with Disabilities came into force in May 2008(6), new norms aimed at ensuring full and effective participation and inclusion of disabled people in society - without discrimination of any nature and equality of opportunities - were issued in Brazil. Law no 13,146(7), of July 6, 2015, known as the Disabled People's Statute, sought inclusion of disabled people. It brought in modern concepts and established that when disability assessments were needed, they would be biopsychosocial and conducted by a multiprofessional interdisciplinary team. Such reviews would consider the following: a) impediments to body functioning and structures; b) socio-environmental, psychological, and personal factors; c) limitations on performing activities; and d) restrictions on participation.

This study aimed to analyse the ethical and legal foundation of the Brazilian legislation for disabled people. Also, ascertain whether instruments in use are compliant with international and national law, and research the coherence and cohesion of the law and its ethical standards to construct an inclusive and fair society. Therefore, an exploration of specific legislation regarding disabled people in Brazil was conducted. The hierarchy of norms and its amenability with the provisions of the United Nations Convention were analysed. Moreover, contradictions between the legal statutes were verified, and the regulation of disabled people's rights was examined.

\section{Material and method}

The methodology used was one of exploratory and integrative review. An examination of legal statutes relating to disabled people's rights was conducted using the official Brazilian Federal government's internet websites (www.planalto.gov. br, www.in.gov.br, www.normas.receita.fazenda. gov.br, www.receita.economia.gov.br, www.bvsms.saude.gov.br and www.sit.trabalho.gov.br).

This methodology was adopted because of the lack of search filters for this type of investigation. The analysis consisted of identifying the content of statutes and assessing whether they fit the objective of this study. After selecting, the material was grouped following: a) the definition of disability and disabled people; b) the specific criteria defined for assessing disability (International Classification of Functionality, ICF; or International Classification of Diseases, ICD); c) disability assessments regarding their biomedical or biopsychosocial nature; d) whether assessments were performed exclusively by doctors or multi-professional; and e) the management body responsible for disabilities' assessment.

\section{Results and Discussion}

Table 1 summarises the legislation, and Table 2 illustrates the norms that fit within one or more of the criteria used in this research methodology. It was found that among the examples selected, particularly those that made provisions regarding certain benefits, did not incorporate criteria for defining disabled people and did not present any assessment parameters in the legal text.

Law no 7,070/1982(8) authorised the executive power to grant a lifelong non-transferable special monthly pension to individuals with the physical disability known as thalidomide syndrome who applied for this. The amount of the special allowance would be calculated as a function of a score that indicated the nature and degree of the dependence resulting from these individuals' physical deformity. Regarding the nature of the dependency, this would include their incapacity to work, mobility, execute personal hygiene, and feed themselves. A score of one or two points would be attributed, respectively, according to whether the dependence was partial or total. Recognition that the benefit dealt with in this law should be granted would depend only on present- 
ing a medical certificate proving the conditions needed to fit within the terms. An official medical board would adjudicate the case constituted for this purpose by the National Institute for Social Security.

Law no $7,713 / 1988$ (11) determined that the following would be exempt from income tax: earnings from retirement pensions or military retirement pensions that were awarded because of work-related accidents; and those awarded due to occupational diseases, active tuberculosis, mental alienation, multiple sclerosis, malignant neoplasia, blindness, leprosy, irreversible and incapacitating paralysis, severe cardiopathy, Parkinson's disease, ankylosing spondylarthrosis, severe nephropathy, severe hepatopathy, advanced stages of Paget's disease (deforming osteitis), radiation contamination and acquired immunodeficiency syndrome. These determinations would be based on conclusions from specialised medicine, even if the disease onset occurred after the retirement date.

Law $\mathrm{n}^{\circ} 8,112 / 1990$ (12) determined that disabled people would be guaranteed the right to enrol in public employment competitions for positions compatible with their disabilities. For such individuals, up to $20 \%$ of the vacancies offered through the competition would be reserved. Reservation of job positions is also regulated through decree no 3,298/99(5), which makes provisions regarding the national policy for integrating disabled people. These decrees defined disability as all losses or abnormalities of structures or psychological, physiological, or anatomical functions that lead to incapacity to perform an activity within the standards considered normal for humans. In addition, five categories were created, with the following clinical criteria: a) physical impairment; b) hearing impairment; c) visual impairment; d) mental impairment; and e) multiple impairments. Decree no 9,508/18(13) provided for reservation of at least $5 \%$ of the vacancies for public employment positions through public competitions and selective processes within the direct and indirect Federal public administration sphere for disabled people. The disability declared by the candidate would be certified by a multi-professional team formed by three professionals with capacitation in the field of the disabilities that the candidate presented, among whom one should be a doctor, and by three professionals working within the career for which the candidate has applied.

Law no 8,213/1991(14) determined that companies with 100 or more employees had an obligation to fill $2 \%$ to $5 \%$ of their positions with suitably skilled disabled people or beneficiaries of rehabilitation. Law no 12,764/2012(15) instituted the national policy for protecting the rights of people with autistic spectrum disorder and defined the clinical criteria for this condition. These individuals would be considered disabled for all legal purposes. Normative instruction SIT/MTE no 98/2012(16) made provisions regarding the procedures for inspecting employers' compliance with the norms for inclusion within the employment of disabled people and beneficiaries of rehabilitation through social security. In this norm, the basis for characterisation of individuals' conditions was decree no 3,298/99(5).

Law no 8,383/1991(17) determined that financial operations regarding acquiring passenger vehicles for disabled people would be exempted from the tax financial operations (IOF). The vehicle licensing authority (DETRAN) of their state's permanent residency, through specific medical certification, should attest to the disability. The cars should be manufactured in Brazil (up to a crude power level of 127 horsepower as classified normatively by the Society of Automotive Engineers), or hybrid and electric.

Law no 8,989/1995(18) (as altered through law $\left.\mathrm{n}^{\circ} 10,690 / 03(19)\right)$ determined that purchases of passenger cars manufactured in Brazil would be exempted from the tax on industrialised products (IPI). These vehicles should be acquired by individuals with physical, visual, severe, or profound mental disabilities, or by autistic individuals, either directly or through the intermediary of their legal representative.

The benefit established in article 1 of the abovementioned law requires individuals to be physically disabled, presenting complete or partial alteration of one or more body segments that entailed physical function impairment, specifically: paraplegia, paraparesis, monoplegia, monoparesis, tetraplegia, tetraparesis, triplegia, triparesis, 
hemiplegia, hemiparesis, amputation, or absence of a limb, cerebral palsy or limbs with congenital or acquired deformity, except for esthetic deformities and those that did not produce difficulties for physical functions. Applications for this benefit would need to be submitted under normative instruction RFB no 1,769/2017(20), which regulated exemptions from IPI relating to the acquisition of vehicles by disabled people. A digitised copy of the assessment report issued by a public healthcare service provider, or by a private healthcare service provider within the public system, by DETRAN or by a not-for-profit autonomous social service would need to be submitted through the Federal tax department's electronic system for conceding exemption from IPI/ IOF. Interministerial Ordinance SEDH/MS no 2/2003(21) defines the criteria for issuing assessment reports on disabled individuals to obtain an exemption from IPI. It stated that a doctor and psychologist would jointly attest to a condition of profound or severe mental disability or autism by filling out specific forms supplied by the Federal tax department or by bodies or institutions that the tax department defined. Reports relating to mental disability would need to meet the International Classification of Diseases (ICD-10). Only the profound or severe levels of mental disability were to be considered. For autism, diagnostic criteria based on ICD-10 and DSM-IV (Diagnostic and Statistical Manual of Mental Disorders) need to be used.

Law no $10,048 / 2000$ (22) determined that disabled people, older adults aged 60 years or over, pregnant women, breastfeeding women, people carrying young children and obese individuals would be given priority attendance, following the text of law no 13,146/2015(7).

Law $n^{\circ} 10,050 / 2000$ (23) determined that the pension benefit provided for in the civil procedure code would be extended to a child whose disability made work impossible in the absence of a father or mother. Law no 13,183/2015(24) determined that the right to a pension due to the death of an insured person would cease for that person's child, partner, or sibling upon reaching 21 years of age, except in the case of invalidity or severe disability or mental or intellectual deficiency. Law no $13,135 / 2015$ (25) established that medical experts for social security and, as substitutes, medical expert supervisors within the $\mathrm{Na}$ tional Institute for Social Security and the Ministry of Social Security would be responsible for performing the medical expert activities inherent to the general regime for social security. They would have the task of characterising disability for social security benefits and assistance.

Law no 11,692/2008(26) enabled disabled young adults to participate effectively in Projovem, the national program for the inclusion of young adults. This program was aimed at young adults aged 15 to 29 years and meant to promote their reintegration into the educational process to obtain professional qualifications and human development. It was developed in the following forms: Projovem socio-educational service for adolescents; Projovem for urban areas; Projovem rural knowledge of the earth; and Projovem for workers.

Law no $12,711 / 2012$ (27) determined that in all Federal institutions of higher education, vacancies would be filled proportionally to the total number of vacancies per course and per yeargroup, by people of self-declared black, brown, and indigenous ethnicity and by disabled people, under the terms of the legislation. At a minimum, these ratios would be equal to the respective proportions of black, brown, indigenous, and disabled people in the population of the Federal State (and the Federal District) where the institute was located, as detailed in the latest census conducted by the Brazilian Foundation and Institute for Geography and Statistics (IBGE). Decree ${ }^{\circ}$ $7,824 / 2012$ (28) regulated this law and stated that the form of proof would be supplied under the terms of the legislation in force.

Law $n^{\circ} 12,587 / 2012(29)$ instituted the national policy guidelines for urban mobility, in which $10 \%$ of parking places were bestowed on disabled drivers, who were included through law $\mathrm{n}^{\circ}$ $13,146 / 15(7)$.

Law $n^{\circ} 12,933 / 2013$ (30) determined a benefit of half-price tickets for entry to cinemas, cine-clubs, theatres, musical shows, circuses, educational events, sports events and leisure and entertainment events throughout Brazil, for disabled peo- 
ple and an accompanying person when necessary. The latter will have an identical benefit if the situation of accompaniment is proven. Decree $\mathrm{n}^{\circ}$ $8,537 / 2015$ (31) regulated Law no $12,933 / 2013$ and confirmed the right to half-price entry to the events listed for disabled people, in consonance with the Brazilian law of inclusion.

Complementary law no 142/2013(32) ensured that a retirement pension would be granted through the general regime for social security to insured individuals with disabilities, under the following conditions: a) after 25 years of contributions for men and 20 years for women, in the case of insured individuals with severe disabilities; b) after 29 years of contributions for men and 24 years for women, in the case of insured individuals with moderate disabilities; c) after 33 years of contributions for men and 28 years for women, in the case of insured individuals with mild disabilities; or d) at 60 years of age for men and 55 years of age for women, independent of the degree of disability, provided that a minimum of 15 years of contributions had been made and that the existence of disability for the same period was proven. The assessment would be medical and functional, and the regulations of the executive power would define severe, moderate, and mild disabilities for this complementary law. Decree no 3,048/1999(33) stated that the National Institute for Social Security (INSS) responsibilities were fulfilled provided it had access to insured individual's information regarding the number of registered mild, moderate or severe disabilities; and biopsychosocial evaluations were conducted by an interdisciplinary multi-professional team (text given through decree $n^{\circ} 10,410 / 20$ (34)) to recognise and maintain rights.

Decree $n^{\circ} 8,145 / 2013$ (35) established that retirement pensions to disabled people under the terms of joint memoranda of the Chief Minister of the Department of Human Rights of the Presidency of the Republic, the Ministries of Social Security, Finance and Planning, Budget and Administration, and the Federal Attorney-General, the expert from the INSS would have the following responsibilities: a) to assess the insured individual and establish a probable date for onset of the disability and its degree; b) to identify occurrences of changes to the degree of disability and indicate the respective periods during which each degree was present. Proof of disability before the date on which complementary law n ${ }^{\circ} 142$, of May 8 , 2013 , came into force and was governed by documents that supported the medical and functional assessments. Proof submitted solely as witness statements would be prohibited. Furthermore, assessments on disabled people would be performed to prove this condition solely for social security purposes.

Law no 8,899/1994(36): This instituted the concession of free public transport passes for disabled people who were proven to need this. Decree $\mathrm{n}^{\circ}$ 3,691/2000(37) regulated this law. It determined that companies with permits and authorisations for the provision of interstate passenger transportation would reserve two seats in conventional services for occupation by disabled people and other matters foreseen in this law. Ordinance $n^{\circ}$ 502/2009(38) instituted certification through multi-professional teams for identifying disabled people within the public healthcare system, intending to grant free passes. Ordinance GM n ${ }^{\circ}$ 410/2014(39) ensured that, within the interstate public system for rail, road, and water-borne transportation, a person accompanying the beneficiary of the free pass program would receive the same benefit, under the following conditions: a) proof of the accompanying person's financial insufficiency, under the terms of Interministerial Ordinance $n^{\circ} 3$, of April 10, 2001, and Ordinance $n^{\circ}$ 261, of December 3, 2012; b) proof, through a medical report, of the indispensability of the accompanying person's presence for the beneficiary's movement. Decree no 3,047/2016(40) established the concession of free passes for people with hearing deficiencies that were proven to be partial or total bilaterally, of $41 \mathrm{~dB}$ or more, measured on an audiogram, regarding the mean from frequencies of $500 \mathrm{~Hz}, 1,000 \mathrm{~Hz}, 2,000 \mathrm{~Hz}$ and $3,000 \mathrm{~Hz}$.

Thirty-three legal norms were found, among which only three laws and two decrees were in line with the recommendations in the Convention on disabled people's rights. Table 1 below emphasises the legislation.

Law no 7,070/1982(8) granted special pensions to people with thalidomide syndrome. The ben- 
eficiaries would present a medical certificate to attest to the dependence resulting from physical deformity (work and mobility incapacity), personal hygiene, and feeding autonomy. The insured person would go through a medical expert assessment at the INSS, but no biopsychosocial evaluation would be necessary despite all the social repercussions.

Complementary law no 142/13(32), which dealt with retirement pensions for disabled people insured through the general regime for social security, was hierarchically higher than ordinary laws, decrees, and ordinances. Its text brought in the modern concept of disabled people and established that assessments of disabilities should be medical and functional (ICD/ICF). Experts from the INSS would certify the degree of disability. However, it was observed that decree $\mathrm{n}^{\circ}$ 3,048/99(33), which made provisions regarding social security regulations, came to determine through the modification imposed by decree $\mathrm{n}^{\circ}$ $10,410 / 20$ (34) that the assessment of the disability would be biopsychosocial and multi-professional, thus differing from what was recommended through the above complementary law. In turn, decree no 8,145/13(35) also adopted the current concept of disability, with medical and functional assessments of disability made by experts from the INSS. In this regard, the norms contradicted each other. They did not follow Hans Kelsen's pyramid hierarchy, i.e., the pure law theory, since the decrees differed from the complementary law.

Law no 8,899/94(36), which ensured the right to free transportation passes for disabled people who were proven to need this, did not establish any need to evaluate the disability or any criteria for characterising disabled people. Nonetheless, decree no 3,691/00(37), which regulated this law, referred to decree $n^{\circ} 10,048 / 2000(22)$, as altered through law no $13,146 / 2015$ (7), which made provisions regarding the disabled people's statute. Furthermore, concerning free passes, ordinance MS no 502/09(38) instituted certification by multi-professional teams for identifying disabled people, done through the public healthcare system, with medical and functional assessments. Likewise, the basis of ordinance GM $n^{\circ} 410 / 14(39)$ and decree no 3,047/16(40) con- sisted of medical and functional assessments, as contained in decree $n^{\circ} 3,298 / 99$ (5).

The percentage of parking places for urban mobility was ensured for disabled people under law $n^{\circ} 13,146 / 2015(7)$. The benefit of half-price tickets for entry to cinemas, cine-clubs, theatres, musical shows, circuses and educational, sports and leisure events was envisaged through decree $n^{\circ} 8,537 / 2015(31)$.

The present study sought to analyse the Brazilian legislation for people with disabilities and verify whether the instruments used to meet what the legislation recommends and investigate the coherence and cohesion of the laws in question. It was observed the inexistence, in the law, of an instrument for the evaluation of disability.

The Convention on the Rights of Persons with Disabilities(6), which came into force on May 3 2008, has as its principles respect for independence, freedom to make one's own choices; nondiscrimination; full and effective participation in society; respect for difference; equality of opportunity; accessibility; equality between men and women; and respect for the developmental capacity of children with disabilities.

According to John Rawls, they are born into some particular conditions within society. These are simply natural facts. What is just or unjust is how social institutions deal with these facts(41).

In the Convention on the Rights of Persons with Disabilities, Rawl's theory portrays principles that make society more just for Persons with Disabilities. However, we acknowledged in the legislation studied an incongruence between the legal texts, the principles governing the Convention, and the absence of standardisation in the criteria for evaluating disability.

The legislation affronts the bioethical principles of beneficence (to do good) and the principle of justice (as the equity that guarantees to give to each person according to their needs) by not establishing uniform criteria to prevent individuals who present deformities without functional repercussion to benefit from rights guaranteed to PWD that present functional deficit and, there- 
fore, disadvantages concerning the so-called ordinary people.

\section{Conclusion}

The comprehensive analysis concluded that the existing legal instruments differ regarding the guarantees for the various benefits for disabled people, with multiple concepts, parameters, and models for assessments.

Given the legal instruments' diversity regarding different rights, and the difficulty in accessing the information relating to these rights and their respective norms, there is a need to publish a document containing all the legislation on this topic. This solution will facilitate search, access and enable better-organised assessments. It will also promote proper understanding among other professionals and the public regarding this topic.
The existence of various rights and benefits for disabled people leads to a need to revise, redraft and consolidate laws, decrees, ordinances, and normative instructions regarding disabled people's rights uniformly. This task needs a reasonable technicalscientific basis that is coherent with the provisions of the 1988 Brazilian Federal Constitution, the International Convention on Disabled People's Rights and the Brazilian Law of Inclusion.

Table 1.

\begin{tabular}{|c|c|c|c|c|c|}
\hline Law/Decree & $\begin{array}{l}\text { Law/Decree } \\
\text { Definition of PWD } \\
\text { following } \\
\text { Convention on the } \\
\text { Rights of the PWD }\end{array}$ & $\begin{array}{l}\text { Disability } \\
\text { evaluation } \\
\text { (ICF/CID) }\end{array}$ & $\begin{array}{l}\text { Biopsychosocial } \\
\text { evaluation }\end{array}$ & $\begin{array}{l}\text { Medical } \\
\text { evaluation/MP* }\end{array}$ & $\begin{array}{l}\text { Responsible } \\
\text { government } \\
\text { body }\end{array}$ \\
\hline Law 7070/82 & no & CID & no & medical & INSS \\
\hline Law 7713/88 & no & CID & no & medical & SUS \\
\hline Law 8383/91 & no & CID & no & medical & DETRAN \\
\hline Law 8989/95 & no & CID & no & medical & DETRAN \\
\hline $\begin{array}{l}\text { Law 8112/90 } \\
\text { Dec 3298/99 }\end{array}$ & no & CID & no & medical & $\mathrm{NE}^{* *}$ \\
\hline Dec 9508/18 & yes & CIF/CID & yes & MP & $\mathrm{NE}$ \\
\hline LC142/13 & yes & CIF/CID & - & medical & INSS \\
\hline Dec $10410 / 20$ & yes & CIF/CID & yes & MP & INSS \\
\hline Dec $8145 / 13$ & yes & CIF/CID & yes & medical & INSS \\
\hline Dec $8537 / 15$ & yes & CIF/CID & yes & MP & SUS \\
\hline
\end{tabular}

* Multiprofissional.

** Not specified. Depends on the institution responsible for the selection process. 
Table 2.

\begin{tabular}{|c|c|c|}
\hline $\begin{array}{l}\text { The legal text uses the current } \\
\text { definitions of disability and } \\
\text { disabled people }\end{array}$ & $\begin{array}{l}\text { Law no } 13,146 / 2015 \\
\text { Law no } 10,048 / 2000\end{array}$ & $\begin{array}{l}\text { Retirement pensions for disabled people insured } \\
\text { through the general regime for social security } \\
\text { Brazilian law of inclusion } \\
\text { Gives priority for attendance } \\
\text { Makes provisions regarding the benefit of half- } \\
\text { price tickets for entry to artistic, cultural and } \\
\text { sports events }\end{array}$ \\
\hline $\begin{array}{l}\text { The legal text uses the ICD/ } \\
\text { ICF criteria for evaluating } \\
\text { disability }\end{array}$ & $\begin{array}{l}\text { Complementary law no } 142 / 2013 \\
\text { Law no } 13,146 / 2015 \\
\text { Decree no } 9,508 / 2018 \\
\text { Law no } 12,764 / 2012 \\
\text { Ordinance } n^{\circ} \text { IM SEDH/MS } \\
\text { 2/2003 }\end{array}$ & $\begin{array}{l}\text { Retirement pensions for disabled people insured } \\
\text { through the general regime for social security } \\
\text { Brazilian law of inclusion } \\
\text { Percentage of public jobs and positions } \\
\text { Protection for the rights of people with autistic } \\
\text { spectrum disorder } \\
\text { Exemption from IPI for individuals with } \\
\text { profound or severe mental deficiency or autism }\end{array}$ \\
\hline $\begin{array}{l}\text { The legal text states that } \\
\text { the assessment should be } \\
\text { biopsychosocial }\end{array}$ & $\begin{array}{l}\text { Law } n^{\circ} 13,146 / 2015 \\
\text { Decree } n^{\circ} 9,508 / 2018 \\
\text { Decree } n^{\circ} 10,410 / 2020\end{array}$ & $\begin{array}{l}\text { Brazilian law of inclusion } \\
\text { Percentage of public jobs and positions } \\
\text { Alters social security regulations }\end{array}$ \\
\hline $\begin{array}{l}\text { The legal text states that the } \\
\text { assessment should be multi- } \\
\text { professional }\end{array}$ & $\begin{array}{l}\text { Law no } 13,146 / 2015 \\
\text { Decree no 9,508/2018 } \\
\text { Ordinance no IM SEDH/MS } \\
2 / 2003\end{array}$ & $\begin{array}{l}\text { Brazilian law of inclusion } \\
\text { Percentage of public jobs and positions } \\
\text { Exemption from IPI for individuals with } \\
\text { profound or severe mental deficiency or autism }\end{array}$ \\
\hline $\begin{array}{l}\text { Legal text states which body } \\
\text { should be responsible for } \\
\text { assessing disabled people }\end{array}$ & $\begin{array}{l}\text { Complementary law no } 142 / 2013 \\
\text { - INSS } \\
\text { Law no } 13,146 / 2015 \text { - INSS }\end{array}$ & $\begin{array}{l}\text { Retirement pensions for disabled people insured } \\
\text { through the general regime for social security }\end{array}$ \\
\hline
\end{tabular}


Legislation for disabled people in Brazil. From human dignity to social inclusion - Rosylane Nascimento das Mercês Rocha et al.

\section{References}

1. das Mercês Rocha RN, Fernandes FC, da Cruz Bezerra J, Nunes R. Comparative Study on Evaluations Conducted by Medical Doctors and Social Workers in which the Adapted Brazilian Functionality Index for Granting Retirement to Persons with Disability Was Applied. International Archives of Medicine 2019; 12.

2. Nunes R. Deafness, Genetics and Dysgenics. Medicine, Health Care and Philosophy. 2006 2006/03/01; 9(1): 25-31.

3. Brasil. Constituição Federativa do Brasil de 1988. Available at: http://www.planalto.gov.br/ccivil_03/constituicao/constituicao.htm.

4. Brasil. Lei ñ 7.853, de 24 de outubro de 1989. Dispóe sobre o apoio às pessoas portadoras de deficiência, sua integração social, sobre a Coordenadora Nacional para Integração da Pessoa Portadora de Deficiência - Corde, institui a tutela jurisdicional de interesses coletivos ou difusos dessas pessoas, disciplina a atuaçáo do Ministério Público, define crimes. Available at: http://www.planalto.gov.br/ccivil_03/leis/l7853.htm.

5. Brasil. Decreto $n^{\circ} 3.298$, de 28 de dezembro de 1999. Regulamenta a Lei $n^{\circ} 7.853$, de 24 de outubro de 1989 , dispóe sobre a Política Nacional para a Integração da Pessoa Portadora de Deficiência, consolida as normas de proteção. Available at: http://www.planalto.gov.br/ccivil_03/decreto/d3298.htm.

6. Crosara de Resende AP, de Paiva Vital FM. (Coords.) A Convençâo sobre Direitos das pessoas com Deficiência Comentada. Brasília: Secretaria Especial dos Direitos Humanos; 2008: 164.

7. Brasil. Lei $n^{\circ}$ 13.146, de 6 de julho de 2015. Institui a Lei Brasileira de Inclusão da Pessoa com Deficiência (Estatuto da Pessoa com Deficiência). Available at: http://www.planalto.gov.br/ccivil_03/_ato2015-2018/2015/lei/l13146.htm.

8. Brasil. Lei ñ 7.070, de 20 de dezembro de 1982. Dispóe sobre pensão especial para os deficientes físicos que especifica e dá outras providencias. Available at: http://www.planalto.gov.br/ccivil_03/leis/1980-1988/17070.htm.

9. Brasil. Lei no 8.686, de 20 de julho de 1993. Dispóe sobre o reajustamento da pensão especial aos deficientes físicos portadores da Síndrome de Talidomida, instituída pela Lei no 7.070, de 20 de dezembro de 1982. Available at: http:// www.planalto.gov.br/ccivil_03/leis/1989_1994/L8686.htm.

10. Brasil. Lei $n^{\circ} 12.190$, de 13 de janeiro de 2010. Concede indenização por dano moral às pessoas com deficiência física decorrente do uso da talidomida, altera a Lei no 7.070, de 20 de dezembro de 1982. Available at: http://www.planalto. gov.br/ccivil_03/_ato2007-2010/2010/lei/112190.htm.

11. Brasil. Lei ñ 7.713, de 22 de dezembro de 1988. Altera a legislação do imposto de renda. Available at: http://www.planalto.gov.br/ccivil_03/leis/l7713.htm.

12. Brasil. Lei no 8.112, de 11 de dezembro de 1990. Dispóe sobre o regime jurídico dos servidores públicos civis da União, das autarquias e das fundações públicas. Available at: http://www.planalto.gov.br/ccivil_03/leis/18112cons.htm.

13. Brasil. Decreto $n^{\circ} 9.508$, de 24 de setembro de 2018. Reserva às pessoas com deficiência percentual de cargos e de empregos públicos ofertados em concursos públicos e em processos seletivos no âmbito da administração pública federal direta e indireta. Available at: http://www.planalto.gov.br/ccivil_03/_ato2015-2018/2018/decreto/d9508.htm.

14. Brasil. Lei no 8.213, de 24 de julho de 1991. Dispóe sobre Planos de Benefícios da Previdência Social. Available at: http:// www.planalto.gov.br/ccivil_03/leis/18213cons.htm.

15. Brasil. Lei $n^{\circ} 12.764$, de 27 de dezembro de 2012. Institui a Política Nacional de Proteção dos Direitos da Pessoa com Transtorno do Espectro Autista e altera o $\$ 3^{\circ}$ do art. 98 da Lei no 8.112, de 11 de dezembro de 1990. Available at: http://www.planalto.gov.br/ccivil_03/_ato2011-2014/2012/lei/112764.htm.

16. Brasil. Ministério do Trabalho e Emprego. Secretaria de Inspeção do Trabalho. Instrução Normativa no 98 , de 15 de agosto de 2012. Dispóe sobre procedimentos de fiscalização do cumprimento, por parte dos empregadores, das normas destinadas à inclusão no trabalho das pessoas com deficiência e beneficiários da Previdência Social reabilitados. Available at: https://sit.trabalho.gov.br/portal/images/SST/SST_legislacao/SST_portarias_2012/Instrucao_Normativa_98_Fiscalizacao_Deficientes.pdf.

17. Brasil. Lei ñ 8.383, de 30 de dezembro de 1991. Institui a Unidade Fiscal de Referência, altera a legislação do imposto de renda. Available at: http://www.planalto.gov.br/ccivil_03/leis/18383.htm.

18. Brasil. Lei no 8.989, de 24 de fevereiro de 1995. Dispóe sobre a Isenção do Imposto sobre Produtos Industrializados - IPI, na aquisiçáo de automóveis para utilização no transporte autônomo de passageiros, bem como por pessoas portadoras de deficiência física. Available at: http://www.planalto.gov.br/ccivil_03/leis/18989.htm.

19. Brasil. Lei $n^{\circ}$ 10.690, de 16 de junho de 2003. Reabre o prazo para que os Municípios que refinanciaram suas dívidas junto à união possam contratar empréstimos ou financiamentos, dá nova redação à Lei $\mathrm{n}^{\circ} 8989$, de 24 de fevereiro de 1995. Available at: http://www.planalto.gov.br/ccivil_03/leis/2003/110.690.htm.

20. Brasil. Instrução Normativa RFB $n^{\circ} 1.769$, de 18 de dezembro de 2017. Disciplina a aplicação da isenção do Imposto sobre Produtos Industrializados (IPI) e do Imposto sobre Operaçôes de Crédito, Câmbio e Seguro, ou relativas a Títulos e Valores Mobiliários (IOF), na aquisição de veículos por pessoas com deficiência física, visual, mental severa ou 
profunda, ou autistas. Available at: http://normas.receita.fazenda.gov.br/sijut2consulta/link.action?visao=anotado\&id Ato $=88750$.

21. Portaria Interministerial SEDH/MS n $n^{\circ} 2$ de 21 de novembro de 2003. Define critérios e requisitos para emissão de laudos de avaliação de Pessoas Portadoras de Deficiência Mental Severa ou Profunda, ou autistas, com a finalidade da obtenção da isençáo do Imposto sobre Produtos Industrializados (IPI), na Aquisição de Automóveis para Utilização no Transporte Autônomo de Passageiros, diretamente ou por intermédio de seu representante legal. Available at: http://receita.economia.gov.br/orientacao/tributaria/isencoes/documentos/portaria-sedh-ms-2-2003.pdf/view.

22. Brasil. Lei $n^{\circ}$ 10.048, de 8 de novembro de 2000. Dá prioridade de atendimento às pessoas que especifica. Available at: http://www.planalto.gov.br/ccivil_03/leis/110048.htm.

23. Brasil. Lei $n^{\circ} 10.050$, de 14 de novembro de 2000. Altera o art. ${ }^{\circ} 1.611$ da Lei no 3.071, de $1^{\circ}$ de janeiro de 1916 - Código Civil, estendendo o benefício do $\$ 2^{\circ}$ ao filho necessitado portador de deficiência. Available at: http://www.planalto.gov. br/ccivil_03/LEIS/L10050.htm.

24. Brasil. Lei $n^{\circ} 13.183$, de 4 de novembro de 2015. Altera as Leis $n^{\circ}$ 8.212, de 24 de julho de 1991, e 8.213, de 24 de julho de 1991, para tratar da associação do segurado especial em cooperativa de crédito rural e, ainda essa última, para atualizar o rol de dependentes, estabelecer regra de não incidência do fator previdenciário, regras de pensão por morte e de empréstimo consignado, a Lei no 10.779 , de 25 de novembro de 2003, para assegurar pagamento do seguro-defeso para familiar que exerça atividade de apoio à pesca, a Lei no 12.618 , de 30 de abril de 2012, para estabelecer regra de inscrição no regime de previdência complementar dos servidores públicos federais titulares de cargo efetivo, a Lei $\mathrm{n}^{\circ}$ 10.820 , de 17 de dezembro de 2003, para dispor sobre o pagamento de empréstimos realizados por participantes e assistidos com entidades fechadas e abertas de previdência complementar e a Lei $\mathrm{n}^{\circ}$ 7.998, de 11 de janeiro de 1990 . Available at: http:/www.planalto.gov.br/ccivil_03/_ato2015-2018/2015/lei/l13183.htm.

25. Brasil. Lei $n^{\circ} 13.135$, de 17 de junho de 2015. Altera as Leis no 8.213, de 24 de julho de 1991, no 10.876 , de 2 de junho de 2004, no 8.112, de 11 de dezembro de 1990, e no 10.666, de 8 de maio de 2003. Available at: http://www.planalto. gov.br/ccivil_03/_ato2015-2018/2015/lei/113135.htm.

26. Brasil. Lei $n^{\circ} 11.692$, de 10 de junho de 2008. Dispóe sobre o Programa Nacional de Inclusão de Jovens - Projovem, instituído pela Lei no 11.129, de 30 de junho de 2005; altera a Lei ${ }^{\circ} 10.836$, de 9 de janeiro de 2004; revoga dispositivos das Leis $\mathrm{n}^{\circ}$ 9.608, de 18 de fevereiro de 1998, 10.748, de 22 de outubro de 2003, 10.940, de 27 de agosto de 2004, 11.129, de 30 de junho de 2005, e 11.180, de 23 de setembro de 2005. Available at: http://www.planalto.gov.br/ ccivil_03/_ato2007-2010/2008/lei/l11692.htm.

27. Brasil. Lei $n^{\circ}$ 12.711, de 29 de agosto de 2012. Dispóe sobre o ingresso nas universidades federais e nas instituiçóes federais de ensino técnico de nível médio e dá outras providências. Available at: http://www.planalto.gov.br/ccivil_03/_ ato2011-2014/2012/lei/112711.htm.

28. Brasil. Decreto $n^{\circ} 7.824$, de 11 de outubro de 2012. Regulamenta a Lei no 12.711 , de 29 de agosto de 2012, que dispóe sobre o ingresso nas universidades federais e nas instituiçóes federais de ensino técnico de nível médio. Available at: http://www.planalto.gov.br/ccivil_03/_ato2011-2014/2012/decreto/d7824.htm.

29. Brasil. Lei $n^{\circ} 12.587$, de 3 de janeiro de 2012. Institui as diretrizes da Política Nacional de Mobilidade Urbana; revoga dispositivos dos Decretos-Leis no 3.326, de 3 de junho de 1941, e 5.405, de 13 de abril de 1943, da Consolidação das Leis do Trabalho (CLT), aprovada pelo Decreto-Lei $n^{\circ}$ 5.452, de $1^{\circ}$ de maio de 1943, e das Leis no 5.917, de 10 de setembro de 1973, e 6.261, de 14 de novembro de 1975. Available at: http://www.planalto.gov.br/ccivil_03/_ato20112014/2012/lei/l12587.htm.

30. Brasil. Lei $n^{\circ} 12.933$, de 26 de dezembro de 2013. Dispóe sobre o benefício do pagamento de meia-entrada para estudantes, idosos, pessoas com deficiência e jovens de 15 a 29 anos comprovadamente carentes em espetáculos artístico-culturais e esportivos, e revoga a Medida Provisória no 2.208, de 17 de agosto de 2001. Available at: http://www.planalto.gov. br/ccivil_03/_ato2011-2014/2013/lei/112933.htm.

31. Brasil. Decreto $n^{\circ} 8.537$, de 5 de outubro de 2015. Regulamenta a Lei ${ }^{\circ} 12.852$, de 5 de agosto de 2013 , e a Lei ${ }^{\circ}$ 12.933 , de 26 de dezembro de 2013, para dispor sobre o benefício da meia-entrada para acesso a eventos artísticoculturais e esportivos e para estabelecer os procedimentos e os critérios para a reserva de vagas a jovens de baixa renda nos veículos do sistema de transporte coletivo interestadual. Available at: http://www.planalto.gov.br/ccivil_03/_ato20152018/2015/decreto/D8537.htm.

32. Brasil. Lei Complementar $n^{\circ} 142$, de 8 de maio de 2013. Regulamenta o $₫ 1^{\circ}$ do art. ${ }^{\circ} 201$ da Constituição Federal, no tocante à aposentadoria da pessoa com deficiência segurada do Regime Geral de Previdência Social - RGPS. Available at: http://www.planalto.gov.br/ccivil_03/leis/lcp/lcp142.htm.

33. Brasil. Decreto $n^{\circ} 3.048$, de 6 de maio de 1999. Aprova o Regulamento da Previdência Social. Available at: http://www. planalto.gov.br/ccivil_03/decreto/d3048.htm.

34. Brasil. Decreto $n^{\circ}$ 10.410, de 30 de junho de 2020. Altera o Regulamento da Previdência Social, aprovado pelo Decreto no 3.048, de 6 de maio de 1999. Available at: http://www.planalto.gov.br/ccivil_03/_ato2019-2022/2020/decreto/ D10410.htm. 
Legislation for disabled people in Brazil. From human dignity to social inclusion - Rosylane Nascimento das Mercês Rocha et al.

35. Brasil. Decreto $n^{\circ} 8.145$, de 3 de dezembro de 2013. Altera o Regulamento da Previdência Social - RPS, aprovado pelo Decreto no 3.048, de 6 de maio de 1999, para dispor sobre a aposentadoria por tempo de contribuição e por idade da pessoa com deficiência. Available at: http://www.planalto.gov.br/ccivil_03/_ato2011-2014/2013/decreto/d8145.htm.

36. Brasil. Lei $n^{\circ} 8.899$, de 29 de junho de 1994. Concede passe livre às pessoas portadoras de deficiência no sistema de transporte coletivo interestadual. Available at: http://www.planalto.gov.br/ccivil_03/leis/18899.htm.

37. Brasil. Decreto $n^{\circ}$ 3.691, de 19 de dezembro de 2000. Regulamenta a Lei no 8.899, de 29 de junho de 1994, que dispóe sobre o transporte de pessoas portadoras de deficiência no sistema de transporte coletivo interestadual. Available at: http://www.planalto.gov.br/ccivil_03/decreto/d3691.htm.

38. Brasil. Portaria $n^{\circ}$ 502, de 28 de dezembro de 2009. Available at: http://bvsms.saude.gov.br/bvs/saudelegis/sas/2009/ prt0502_28_12_2009.html.

39. Brasil. Portaria GM no 410, de 27 de novembro de 2014. Dá cumprimento ao Acórdão proferido na Ação Civil Pública no 0052380- 68.2010.4.01.3400/DF, pela 5a Turma do Tribunal Regional Federal da 1a Regiáo. Available at: http:// www2.transportes.gov.br/BaseJuridica/Detalhe.asp?Codigo $=15030$.

40. Brasil. Portaria $n^{\circ} 3.407$, de 2 de dezembro de 2016. Estabelece orientação quanto ao conceito de deficiência auditiva para fins de concessão do benefício do Passe Livre. Available at: https://www.in.gov.br/materia/-/asset_publisher/Kujrw0TZC2Mb/content/id/24642484/do1-2016-12-05-portaria-n-3-407-de-2-de-dezembro-de-2016-24642408.

41. Rawls J. Uma Teoria da Justiça. Tradução: Jussara Simôes. Revisão técnica e da tradução: Alvaro de Vita. 4. ${ }^{a}$ Rev. ed. São Paulo: Martins Fontes - Selo Martins (Coleção Justiça e Direito); 2016.

Received: July 19, 2021

Accepted: September 27, 2021 